\title{
INTER-INDUSTRY WAGE DIFFERENTIALS IN AUSTRALIA, 1947-1954*
}

\author{
J. KMENTA \\ University of Wisconsin
}

\begin{abstract}
... when the economic theorist turns to the general problem of wage determination and labor economics, his voice becomes muted and his speech halting. If he is honest with himself, he must confess to a tremendous amount of uncertainty and self-doubt concerning even the most basic and elementary parts of the subject.1
\end{abstract}

\section{INTRODUCTION}

In a perfectly competitive equilibrium all workers of a given skill would receive equal remuneration; in real life considerable inter-firm and interindustry wage differentials, of course, exist. These, it has been argued, should be regarded as a normal feature of our economic system. ${ }^{2}$ Thus a majority of empirical research has been concentrated on discovering factors which account for changes in the inter-industry wage differentials rather than for their existence. It has been observed that, in the last few decades, there has existed a tendency for the inter-industry wage differentials to become narrower. ${ }^{3}$ The purpose of this paper is:

(i) to examine the changes in the relative earnings of unskilled workers in the Australian manufacturing sector during the post-war period; and

(ii) to test the significance of a number of factors which may have accounted for the observed changes.

\section{ECONOMIC Models}

A well-known theorem of marginal analysis states that, in conditions of a profit-maximizing equilibrium, the firm's demand for labour of a given type will be given by the equality of price of labour and its marginal revenue product. The marginal revenue product, which is defined as marginal physical product times marginal revenue, depends on the following factors:

* Abstracted from a portion of a doctoral dissertation for Stanford University. The research work on which this paper is based was supported by a Sydney University research grant.

1 "Economic Theory and Wages", in David McCord Wright (ed.), The Impact of the Union (New York: Kelley and Millman, Inc., 1956), p. 312.

2 See, e.g. R. A. Lester, "A Range Theory of Wage Differentials", Industrial and Labor Relations Review, 5 (1952), pp. 483-500.

3 The studies were related to the United States, Great Britain, and several other western countries. To the author's knowledge no examination of the inter-industry wage structure in Australia has been attempted so far. D. W. Oxnam in Wages in Australia, 1913-14 to 1949-50, paper presented to the Australian and New Zealand Association for the Advancement of Science, Brisbane, May 1951, examined the wage differentials between the States of Australia and found a similar tendency. 
(i) form and parameters of the production function;

(ii) quantity of other factors of production in use (which, in turn, depends on the prices of these factors);

(iii) form and parameters of the product demand curve.

Given these factors, the firm's demand for labour at any given wage can be determined. The industry's demand for labour would then consist of the aggregate of demands of individual firms in the industry. Factors which influence the labour supply curve are more difficult to enumerate. The chief economic factor is the wage earned by the same type of labour in other industries, but non-economic factors are likely to be of considerable importance. The intersection of the demand and supply curve of labour gives the equilibrium average wage paid and quantity of labour employed in the industry. In the long run, labour would move from the low-wage to the high-wage industries, thus effecting shifts in the supply curve of labour, and equality of wages would finally result. ${ }^{4}$ If there are any restrictions on the mobility of labour, inter-industry wage differentials will persist. But other factors apart from the immobility of labour may be operating to perpetuate the existence of wage differentials in real life. First, the equilibrium position may never be attained because of continuous changes in the factors affecting the demand and supply of labour. Secondly, the principle of profit maximization may not apply and the equilibrium position may be determined by other motivational or institutional considerations. Finally, anti-competitive and impeditive influences may weaken the forces of the market mechanism.

The complexity of the system of wage determination was fully recognised by earlier research workers. The problem was re-formulated as one of a dynamic process which could be, at least in part, explained by the existence of measurable systematic influences. The pioneering work was done by $\mathrm{J}$. T. Dunlop who concluded that:

wage and salary rates would be expected to increase most where productivity and output increase most, where labour costs are a small percentage of total costs, where the enterprises are in strong bargaining power with the purchasers of their output, and where technical change operates to increase the skill and raise the occupational rating of employees. ${ }^{5}$

Dunlop's hypothesis can be readily interpreted in terms of theoretical analysis. Increases in productivity of labour and in output result in upward

\footnotetext{
4 Strictly speaking, the equality would apply to total net advantages rather than to money wages alone. The former is, however, a non-operational concept and, therefore, following innumerable precedents, the difference between the two has been disregarded. I wish to thank the anonymous referee for stressing this point.

s "Productivity and the Wage Structure", in Income, Employment and Public Policy: Essays in Honor of Alvin H. Hansen (New York: W. W. Norton and Co. Inc., 1948), p. 960 .
} 
shifts in the industry's demand for labour and thus tend to raise the wage at the equilibrium point. If labour cost represents only a small proportion of total costs, there will be less resistance on the part of the employers to satisfy the claims for higher wages since wage increases will result in only a relatively small reduction of profits, or only in a relatively small increase in the price of the product. A strong bargaining power of the firms with the purchasers of their output implies a near-monopoly position in the product market and a less elastic product demand curve than in the case of competitive firms. The firms are then in a better position to pass on any wage increases in the form of increases in the price of the product. The final factor of Dunlop's hypothesis, the rise in the occupational rating of employees as a result of technological change, is directly applicable only in the case where the average wage of all types of labour is considered. Technological development is likely to result in an increase in the proportion of skilled workers and, consequently, the average wage of workers of all types rises. If we confine ourselves to the study of inter-industry wage differentials with respect to labour of a given skill, the operation of technology to increase the occupational rating of employees becomes relevant only as a factor of nonmonetary remuneration.

Dunlop's proposition represents a catalogue of factors which were considered as the most important systematic determinants of the movements in the inter-industry wage structure. The proposition was deduced in part from statistical evidence ${ }^{8}$ and in part by a priori reasoning. A critical examination of the proposition has to be concerned with the plausibility of excluding other presumably equally worthy candidates from the selected list. In particular, all the factors considered by Dunlop relate to the influences affecting shifts in the demand for labour; no consideration is given to inter-industry differences in shifts of the labour supply curve. The main factor influencing the labour supply curves in different industries could be expected to be the degree of unionisation. However, empirical studies for the United States and Great Britain indicate that, except in the case of new organisations, unionism has had little effect on relative wages in industries. ${ }^{7}$ In relation to the factors which Dunlop did include as representing the major influences on changes in wages, a certain degree of controversy exists with respect to the effect of the state of competition in the product market. The "low-wage" theorists assert that, contrary to Dunlop's proposition, the higher the degree of

6 Productivity and Unit Labor Cost in Selected Manufacturing Industries, 1919-1940 (Bureau of Labor Statistics, Washington, D.C., February 1942).

7 See P. H. Douglas, Real Wages in the United States, 1890-1926 (Boston: Houghton Mifflin Co., 1930), p. 562; A. M. Ross and W. Goldner, "Forces Affecting the Inter-industry Wage Structure", Quarterly Journal of Economics, 64 (1950), p. 269; B. C. Roberts, "Trade Union Behaviour and Wage Determination in Great Britain", in J. T. Dunlop (ed.), The Theory of Wage Determination (London: Macmillan and Co. Ltd., 1957), p. 120; J. E. Maher, "Union, Non-union Wage Differentials", American Economic Review, 46 (1956), pp. 336-352. 
competition in the product market the higher the wage of labour. ${ }^{8}$ The argument is based on the contention that the monopolistic firms are likely to be larger than the competitive ones and thus have a greater monopsony power in the labour market. If, however, labour of a given skill can be employed in several industries, the monopsony power is likely to be rather weak.

The hypothesis put forward by Dunlop has been subjected to empirical tests by a number of research workers. Ross and Goldner ${ }^{\theta}$ applied simple correlation analysis to the data on United States industries for the period 1933 to 1946 and found a positive correlation between changes in average earnings and changes in employment ${ }^{10}$ but failed to discover any simple association between changes in earnings and labour cost proportions. ${ }^{11} \mathrm{~A}$ rough inspection indicated that industries with oligopolistic market structures tended to show greater increases in wages than the more competitive industries. J. W. Garbarino ${ }^{12}$ examined selected industrial groups in the United States during the period 1923 to 1940 and, with the help of simple rank correlation technique, concluded that the movement in the interindustry wage differentials can be largely explained by "the variables of productivity, concentration, and unionisation".18 However, Meyers and Bowlby, 14 using simple rank correlation technique applied to the U.S. manufacturing data beyond 1950 , found no relation between changes in wages and in the productivity of labour. Doris M. Eiseman, ${ }^{15}$ who studied the inter-industry wage changes in the United States between 1939 and 1947 , found a positive correlation between changes in wages and (i) original level of earnings; (ii) changes in production; (iii) changes in employment; (iv) labour costs as a proportion of total costs. The last conclusion, stating that changes in wages varied positively with the ratio of labour costs to total costs, is highly surprising but may be due to the somewhat unorthodox

8 For an exposition of this view see D. Schwartzman, "Monopoly and Wages", Canadian Journal of Economics and Political Science, 26 (1960), pp. 429-430.

$\rightarrow$ Loc. cit., pp. 254-281.

10 Dunlop apparently considered changes in employment and changes in output as substitutable for each other. In his essay "Productivity and the Wage Structure", loc. cit., p. 359, Dunlop states that "... a theory of the inter-industry movement of wage structure must include other factors than changes in productivity and output or employment" (italics mine).

11 Ross and Goldner used labour cost as a percentage of the value of output (i.e. total variable or direct costs plus overheads plus net profit) rather than as a percentage of total costs as suggested by Dunlop.

12 "A Theory of Inter-industry Wage Structure Variation", Quarterly Journal of Economics, 64 (1950), pp. 282-305.

18 Ibid., p. 805 .

14 F. L. Meyers and R. L. Bowlby, "The Inter-industry Wage Structure and Productivity", Industrial and Labor Relations Review, 7 (1953), pp. 94-99.

15 "Inter-industry Wage Changes, 1939-1947", Review of Economics and Statistics, 38 (1956), pp. 445-448. 
statistical treatment in calculating the correlation coefficient. ${ }^{16}$ Studies of inter-industry wage structure in Great Britain carried out by Salter, Nicholson and Gupta, and Phelps Brown and Browne ${ }^{17}$ all revealed a lack of simple association between changes in earnings and in productivity of labour. Phelps Brown and Browne, however, discovered a positive relationship between change in earnings and in concentration of employment (i.e. proportion of industry's employment given by the three largest firms).

The results of the above empirical investigations, though illuminating, do not have a conclusive bearing on Dunlop's hypothesis. Apart from the difficulties of measurement, one can object to the use of the simple correlation techniques which do not separate out the effects of individual factors. This makes it impossible to use statistical tests of significance unless the factors which may influence the wage differentials vary independently of each other, which is unlikely. The relationship between change in wages and any one particular variable may be blurred by an offsetting influence of some other one or more relevant factors. For instance, a lack of observed relationship between change in wages and in productivity of labour may be due to the fact that labour productivity was growing faster in industries with a low rate of growth of output, and slower in industries in which output was growing more rapidly. A simple rank or product-moment correlation analysis, used almost without exception in the past empirical studies, is thus not very informative.

A theoretical attempt at explaining the inter-industry wage differentials was made more recently by L. Johansen. ${ }^{18}$ Using a highly simplified mathematical model of production, Johansen deduces that "we may expect not changes in wage differentials, but the wage differentials themselves to be correlated with the changes in productivity", and that "the level of the wage rate differential within the model is uniquely correlated with changes in employment". In arriving at this conclusion Johansen makes use of the following assumptions:

(i) the equilibrium wage and employment in any firm is determined by the marginal productivity principle;

(ii) the change in wage is determined by the distance of the actual level

16 The ratio of labour costs to total costs was correlated with the residuals from the regression equation of change in wages on original level of wages. In this case a positive correlation coefficient may be largely a result of a high negative relationship between the ratio of labour costs to total costs and the original level of wages.

17 See W. E. G. Salter, Productivity and Technical Change (London: Cambridge University Press, 1960), ch. XII; R. J. Nicholson and S. Gupta, "Output and Productivity Changes in British Manufacturing Industries", Journal of the Royal Statistical Society (Series A), 123 (1960); E. H. Phelps Brown and M. H. Browne, "Earnings in Industries of the United Kingdom, 1948-59", Economic Journal, 72 (1962), pp. 517-549.

18 "A Note on the Theory of Inter-industrial Wage Differentials", Review of Economic Studies, 25 (1958), pp. 109-113. 
to the equilibrium level of employment, and by the distance of the actual wage paid to the average in the industry;

(iii) there is a tendency on the part of labour to move from low-wage to high-wage industries;

(iv) at any given point of time, output is a parabolic function of labour input only;

(v) there exists a pronounced long-run trend in the productivity of labour in each industry.

We have, then, two alternative theoretical models which may serve as means of detecting the systematic factors underlying the inter-industry wage structure. Further, it seems desirable to take into account the influx of migrants on the Australian labour market after the war-a situation not applicable to the economies contemplated by Dunlop and Johansen. The impact of migrants could be expected to shift the labour supply curves and thus affect the equilibrium wage. To allow for this we shall extend the models to include the supply of migrants as an additional explanatory variable. On theoretical grounds we would expect that wages in industries with a relatively greater number of migrants would tend to be lower compared with industries with relatively few or no migrants. For the purpose of statistical tests of the two hypotheses we assume linear relationships and examine the significance of the coefficients attached to the explanatory variables. The mathematical formulation of the hypotheses is then given by the following expressions:

Model I (Dunlop's)

$$
\Delta W_{1}=a_{0}+a_{1} P_{i}+a_{2} O_{1}+a_{3} C_{4}+a_{4} Z_{6}+a_{5} M_{4}+e_{6}
$$

Model II (Johansen's)

$$
W_{6}=b_{0}+b_{1} P_{i}+b_{2} N_{i}+b_{9} C_{i}+b_{4} Z_{6}+b_{6} M_{i}+e_{6}
$$

The subscript $i$ refers to the $i$-th industry; and

$$
\begin{aligned}
\Delta W= & \text { change in average wage; } \\
W= & \text { average wage at the end of the period; } \\
P= & \text { change in the physical productivity of labour; } \\
O= & \text { change in the volume of output; } \\
C= & \text { labour costs as a proportion of total costs; } \\
Z= & \text { measure of the degree of competition on the product market; } \\
M= & \text { migrant labour as a proportion of total employment; } \\
N= & \text { change in employment; } \\
e= & \text { random disturbance, assumed to be normally distributed with } \\
& \text { zero mean and a constant variance and independent of the } \\
& \text { explanatory variables. }
\end{aligned}
$$

All variables except $O$ and $Z$ refer to a particular occupational type of labour. 
The preceding discussion makes it quite clear that the list of explanatory variables is not complete and that economic theory does not, and can not, take all the complexities of real life into account. This, it was emphasized, is particularly troublesome in the field of labour economics where anticompetitive influences abound. The Australian arbitration system of wage determination is a case in point. However, while the system may weaken the pressures of the market, it is unlikely that it would eliminate them altogether. It is a common and easily ascertainable fact that considerable differences exist between the wage rates determined by the Court and the actual wages paid. This "wage drift" can be regarded as the market correction of the officially made decisions. The observations of the behaviour of wages in Great Britain and other regulated economies of Western Europe serve as an illuminating example. ${ }^{10}$ At the same time, the anti-competitive factors on the labour market are probably stronger in Australia with a long tradition of comprehensive unionisation and Government wage regulation than in most countries of the Western world. ${ }^{20}$ In particular, the "stickiness" which seriously hinders any possibility of a downward adjustment detracts from the validity of the regression models. Further, the validity of the statistical tests depends on the assumptions made about the disturbance term which, under the circumstances, are fairly tenuous. Thus it is recognised at the outset that the test will not provide unqualified results and that, at best, it can throw only a limited light on the forces determining the industrial pattern of wages.

\section{Data}

As mentioned in the introductory part, we are confining ourselves to the study of the wage structure in the manufacturing industries only. This limitation is imposed by the lack of statistical information on other sectors of the economy. The period 1947 to $1954^{21}$ was chosen because it coincides with the dates of the latest Census takings for which comprehensive results are available. The examination of the wage structure is to be concerned with labour of a given occupational type only. The type chosen for this purpose is that of "common" labour, that is, labour which requires little or no occupational training. There is, of course, a difficulty that the type and conditions of work performed by unskilled labour vary from industry to industry. However, this difficulty is to be encountered in most occupations; the relatively large numbers of unskilled workers in any industry are likely

10 See, e.g. J. T. Dunlop and M. Rothbaum, "International Comparisons of Wage Structures", International Labour Review, LXXI (1955), pp. 347-363; L. G. Reynolds and C. H. Taft, The Evolution of Wage Structure (New Haven: Yale University Press, 1956). p. 371 .

20 The fact that all manufacturing industries in Australia are strongly unionised was the main reason for omitting the degree of unionisation from the list of explanatory variables.

21 All annual figures used in this paper refer to the financial year ended 30th June, 1947, and the financial year ended 30 th June, 1954. 
to make industrial averages more homogeneous. Our investigation will refer to workers belonging to the occupational order 6 (operatives) and 7 (labourers) of the Census classification.

The data used in the subsequent sections of the paper have originated from two sources: the annual production bulletins for secondary industries; and the Census publications. ${ }^{22}$ Since the collection of data and the classification of industries used in the two sources are done quite independently, it was necessary to re-group the industries into comparable categories. This was done by forming clusters of technologically or economically related industries and comparing total employment of males in these clusters as shown by the two sources. An approximate equality of total employment then assured that the reconciliation has been successful. ${ }^{23}$ At the end we have obtained 43 industrial classes which represent our units of observation; these classes cover 86 per cent of total manufacturing employment of the year 1954. The details of the classification are given in the Appendix. The definitions and the methods of estimation of the variables required by the two models are described separately for each of the variables below.

(a) Wages

Wages have been defined as gross annual earnings of unskilled male employees. Under this definition wages include overtime and penalty payments in addition to the basic remuneration. This definition, imposed by the nature of available statistics, differs from the "straight-time" earnings used in the empirical studies for the United States. However, the opportunity to work overtime is undoubtedly regarded as desirable by a majority of workers and thus overtime earnings do, in a sense, represent an additional advantage to labour in the industry. Furthermore, if two industries differ only by virtue of the fact that one industry uses overtime labour and the other does not, the change-in-output variable will account for at least some of the difference in the average wage in the two industries. With respect to penalty payments, it is assumed that their incidence does not vary in any substantial way from industry to industry. In any case, the validity of testing Dunlop's model will not be impaired as long as the inter-industry structure of overtime and penalty payments did not change over the period considered.

The information on wages paid to unskilled labour, even if defined as broadly as above, is not directly available. The production bulletin statistics refer to all male manual workers, whether skilled or unskilled; these had to serve as a basis for estimation. The estimate of the average wage of an unskilled male employee was derived from the fact that the average wage

22 Both published by the Commonwealth Bureau of Census and Statistics, Canberra, A.C.T. 23 An exact equality could not be expected since the Census data refer to the total work force, including unemployed, as at the date of the Census whereas the figures in the production bulletins refer to the average annual employment. 
per manual worker represents a weighted average of the wages of unskilled and skilled workers. Two assumptions were made:

(i) the absolute difference in the average wage of the two types of workers is equal to the average award for skill as determined by the Court;24

(ii) the ratio of skilled to unskilled male manual workers in each industry did not change during the period of observation.

The first assumption implies equality of over-award payments (including overtime payments) received by the two types of labour. In other words, the market pressures as reflected by the "wage drift" are assumed to be equally strong in both categories of the labour market. This does not appear to be altogether implausible during a period marked by a general shortage of labour and it is also consistent with the traditional unionist policy of fixed cash differentials for skill. The violation of the assumption is more likely to be due to the existence of differences in the overtime payments rather than in the "inducement" payments. The second assumption was necessitated by the exclusion of occupational statistics from the 1954 Census. However, radical changes in the proportions of skilled and unskilled workers employed are not very likely in as short a period of time as considered by us. If the assumptions are not fulfilled, then our measure refers to the average wage of all male manual workers and corresponds to the measure used in almost all empirical studies in the past..25 If, however, the assumptions are not violated, then our measure constitutes an improvement.

\section{(b) Change in the Physical Productivity of Labour}

Ideally, we would like to have a measure of an increase in physical output due to an addition of one unskilled male worker to the industry's work force. Such a measure is, of course, unobtainable, except by means of an experiment. Thus all research workers concerned with empirical study of interindustry wage structures in the past were forced to use changes in the output per worker or per man-hour. The present study is no exception and, accordingly, the change in the physical productivity of labour was measured by

$$
P_{i}=\frac{\left(V_{1 i} / L_{1 i}\right)}{\left(V_{o i} / L_{o i}\right) \cdot P_{1 i}}
$$

where $V=$ total value of output; $L=$ quantity of labour, measured by the number of "unskilled male equivalents" of all manual workers; $p=$ index of prices of products, $1946-47=1.00$. The subscript $i$ refers to the $i$-th

24 See Minimum Weekly Wage Rate Index (Canberra: Commonwealth Bureau of Census and Statistics, 1961). The margin for skill used in our calculations was a weighted average of Commonwealth and State awards.

25 The one exception known to the author is the study of S. H. Slichter, "Note on the Structure of Wages", Review of Economics and Statistics, 32 (1950), pp. 80-91. 
industry, and the subscript $O$ and 1 to the years $1946-47$ and 1953-54 respectively.

The quantity of labour in terms of unskilled male equivalents, $L$, was obtained by assigning weights to skilled males and skilled and unskilled females. These weights were supposed to reflect the contribution to production by these workers relative to that of an unskilled male. The values, chosen in a somewhat arbitrary fashion, were 1.25 for a skilled male and 1.00 for a female, whether skilled or unskilled.

The index of prices of products for 1953-54 with 1946-47 as a base was estimated by the formula

$$
p_{1 t}=\frac{\left(V_{1 i} / B_{1 i}\right) \cdot p_{1}^{\prime}}{\left(V_{o t} / B_{o t}\right)}
$$

where $p^{\prime}=$ wholesale price index of goods principally home produced, $1946-47=1 \cdot 00 ;{ }^{26} B=$ total wage bill.

The price index calculated in this way is based on the contention that all industries were subjected to a general change in the level of prices (as represented by $p^{\prime}$ ), and that an increase in relative prices was associated with an increase in the percentage gross profit margin. This index is obviously somewhat improvised but had to be used in absence of any other indicators of the movement in prices of products of individual industries.

The change in the physical productivity of labour is described by a ratio rather than by an absolute difference. The former was chosen on the grounds that absolute differences would tend to exaggerate the importance of productivity changes in capital intensive industries (i.e. those in which the initial level average productivity of labour was high), and to underrate the importance of productivity changes in labour intensive industries with a low initial level of labour productivity.

The results of the calculations indicated that the changes in the physical productivity of labour ranged from -15 per cent in the Refining of Nonferrous Metals industry to +10.3 per cent in the Rope and Cordage industry. The average change in the physical productivity of labour over the period considered was $-\mathbf{3 . 0}$ per cent (i.e. $\bar{p}=0.970)$.

\section{(c) Change in the Volume of Output}

The change in the volume of output was measured by the ratio

$$
O_{i}=\frac{V_{1 i}}{V_{\text {oi }} \cdot p_{1 i}}
$$

where $V$ and $p$ are defined as in (b) above. This measure reflects reasonably well the rates of growth (or decline) of individual industries as suggested by Dunlop. Here again, we chose to use ratios rather than absolute differences to make the changes in various industries more comparable. The 26 Year Book of the Commonwealth of Australia (Canberra: Commonwealth Bureau of Census and Statistics, 1960), p. 414. 
mean percentage change was found to be $+16 \cdot 1$ per cent; the highest rate of expansion was shown by the Cement industry $(+92.7$ per cent) and the lowest by the Fur and Wool Processing industry ( -19.9 per cent).

\section{(d) Labour Cost as a Percentage of Total Costs}

Labour cost was defined as the total wages paid to all manual employees. Total costs were defined as total direct costs and included the total value of containers, packing, tools replaced, repairs to plant, all materials used, power, fuel, light, lubricants, and water as well as the total wage bill. The statistics are available in the production bulletin. The percentages obtained for 1946-47 did not markedly differ from those for 1953-54. The variable used in the regression equations was a simple average of the two years. The values ranged from 4.93 per cent in the Tobacco industry to 56.84 per cent in the Stereotyping industry.

\section{(e) Degree of Competition on the Product Market}

A measure of the degree of competition on the product market is notoriously difficult to obtain. Two alternative measures were devised for the purpose of the statistical test but neither can be regarded as fully satisfactory. The first of these is the percentage gross profit margin calculated as the difference between the total value of output and the total operating costs expressed as a percentage of the former. ${ }^{27}$ The total operating costs were defined as the total direct costs plus the estimated value of labour of the working proprietors. This measure assumes short-term profit maximisation and equality of marginal and average costs in each firm; the problem of aggregation is disregarded. The variable was again represented by a simple average of the gross profit percentages for 1946-47 and 1953-54. The lowest gross profit margin was observed in the Fur and Wool Processing industry ( 9.83 per cent), and the highest in the Drugs and Cosmetics industry (55.19 per cent); the average gross profit margin was 27.46 per cent.

As an alternative measure of the degree of competition we have used an index of the concentration of employment. This was calculated, for each industry, as the percentage of total labour force employed by the largest ten per cent of factories in the industry. ${ }^{28}$ The assumption underlying this measure is that of a positive correlation between factory size and firm's size, and between size and monopoly power. The calculated values averaged 51.17 per cent and ranged from 29.8 per cent in the Tyre Retreading industry to 81.7 per cent in the Shipbuilding industry.

27 A similar measure was suggested by A. P. Lerner, "The Concept of Monopoly and the Measurement of Monopoly Power", Review of Economic Studies, 1 (1933-34), Pp. 157-175; M. Kalecki, Essays in the Theory of Economic Fluctuations (London: George Allen \& Unwin, 1939), p. 19; K. W. Rothschild, The Theory of Wages (New York: The Macmillan Co., 1954), p. 165.

28 A similar measure was used by $E_{n}$ H. Phelps Brown and M. H. Browne, loc. cit., p. 540. 
A choice of the two measures implies a choice of one of the two sets of assumptions. A simple correlation coefficient between the two measures rendered a value close to zero, indicating a failure of at least one of the two measures to carry the function imposed upon it.

\section{(f) Unskilled Male Migrant and Non-migrant Employment}

The statistics in the production bulletin do not provide any information about migrants. The Census data show the number of foreign-born in each industry classified by the period of residence in Australia, and the number of foreign born of each occupational status also classified by the period of residence. ${ }^{29}$ Since our period of observation embraces a time-span of seven years, only those migrants who have resided in Australia less than seven years as at the time of the 1954 Census have been considered. This, of course, includes almost all post-war immigrants. We shall, for the sake of simplicity, use the word "migrants" to refer to these immigrants only.

The Census statistics, which include all immigrants, served as a basis for estimating the number of unskilled male migrants in each industry. In describing the estimation procedure we shall use the following notation:

$$
\begin{aligned}
I_{i}^{*} & =\text { number of skilled male employees; } \\
I_{i}^{* *} & =\text { number of unskilled male employees; } \\
M_{i j}= & \text { number of male migrants of } j \text {-th year of residence; } \\
m_{i j}= & \text { number of male migrant employees of } j \text {-th year of residence; } \\
m_{i j}^{*}= & \text { number of skilled male migrant employees of } j \text {-th year of resi- } \\
& \text { dence; } \\
m_{i j}^{* *}= & \begin{array}{l}
\text { number of unskilled male migrant employees of } j \text {-th year of } \\
\text { residence. }
\end{array}
\end{aligned}
$$

The subscript $i$ refers to the $i$-th industry. In accordance with the customary terminology, a dot in place of a subscript represents a sum over the entire range of the subscript. The 1954 Census results give figures for $M_{i j}, m_{i j}$ and $\left(I_{i}^{*}+I_{i}^{* *}\right)$. The following assumptions will be made:

(i) The ratio of skilled to unskilled male employees in each industry in 1954 remained the same as in 1947. That is,

$$
I_{i}^{* *} /\left(I_{i}^{*}+I_{i}^{* *}\right)=k_{i}
$$

where $k_{i}$ has been calculated from the results of the 1947 Census.

(ii) The ratio of skilled to unskilled male migrant employees of $j$-th year of residence is equal to the ratio of all skilled to all unskilled male employees. In terms of our symbols,

$$
m_{i j}^{*} / m_{i j}^{* *}=I_{i}^{*} / I_{i}^{* *}
$$

29 Census categories of occupational status are: employer, self-employed, wage or salary earner, helper, and unemployed. The classification of foreign-born by occupational status and period of residence is not published but can be obtained on request from the Commonwealth Bureau of Census and Statistics, Canberra, A.C.T. 
(iii) The ratio of male migrant employees to all male migrants in the work force, for $j$-th year of residence, is the same in every industry. I.e.

$$
\left(m_{i j}^{*}+m_{i j}^{* *}\right) / M_{i j}=m_{. j} / M_{. j}
$$

Assumption (i) has already been made in connection with the estimation of wages of unskilled male workers; it is necessitated by the lack of occupational classification in the 1954 Census results. Assumption (ii) does not appear to be unreasonable in light of the statistics on the occupational distribution of arrivals. These show that, during the period which we are considering, the ratio of skilled to unskilled workers among immigrants was somewhat higher than in the total Australian work force in $1947 . .^{30}$ It would then seem that, allowing for some degree of occupational degradation of migrants, the proportions in the total work force probably do not differ to any great extent. There may, of course, be some discrepancies in individual industries. Assumption (iii) is also not very troublesome since the proportion of wage earners among migrants of short periods of residence is close to unity and only slowly declines as the period of residence lengthens. ${ }^{31}$ Consequently any large variation is unlikely.

With the use of these three assumptions we arrive at an estimate of the number of unskilled male migrant employees of $j$-th year of residence as given by

$$
m_{i j}^{* \bullet}=k_{i} m_{. j} M_{i j} / M_{. j}
$$

The total number of unskilled male migrants in each industry can be easily obtained by addition over the seven years of residence. This is then expressed as a percentage of total unskilled male employment to measure the required variable in the regression equations. The change in employment $\left(N_{i}\right.$ in Johansen's model) was measured by the ratio of estimated total number of unskilled males in each industry in 1954 to that in 1947.

An interesting feature of the resulting classification of the unskilled male labour force was the apparent displacement of non-migrants by migrants in 22 out of the total of 43 industries. ${ }^{32}$ In these industries the number of unskilled male migrants was greater than the change in the total number of unskilled males. However, there is no evidence that the displacement resulted in unemployment since, according to the Census results, the number of males unable to secure employment declined from 16,489 in 1947 to 9,067 in 1954. The percentage of unskilled male migrant employment in 1954

Bo See, e.g. W. D. Borrie, "Australia's New Population Pattern", in Australian Institute of Political Science, Australia and the Migrant (Sydney: Angus and Robertson, 1953), pp. 45-46.

81 See J. Kmenta, "Economic Mobility of Immigrants in Australia", Economic Record, 37 (1961), pp. 456-469.

82 The 22 industries included all industries (11 in total) in which the total unskilled male labour force appeared to be declining. 
TABLE I

Estimated Wages of Unskilled Male Employees-Industrial Averages

(1) Level of wages, 1947

\begin{tabular}{l|c}
\hline \multicolumn{1}{c|}{$£$} & $\begin{array}{c}\text { Number of } \\
\text { Industries }\end{array}$ \\
\hline Under 280 & 5 \\
280 and under 300 & 11 \\
300 and under 320 & 15 \\
320 and under 340 & 7 \\
340 and under 360 & 4 \\
960 and under 380 & - \\
380 and over & 1 \\
& \\
\hline Total & 43 \\
\hline Mean & 308.14 \\
Standard deviation \\
Coefficient of variation \\
Ratio of upper to lower \\
quartile \\
Ratio of highest to lowest \\
wage
\end{tabular}

(iii) Absolute change in wages, 1947 to 1954

\begin{tabular}{l|c}
\hline & $\begin{array}{c}\text { Number of } \\
\text { Industries }\end{array}$ \\
\hline 360 to 379.9 & 1 \\
380 to 399.9 & 3 \\
400 to 419.9 & 9 \\
420 to 489.9 & 6 \\
440 to 459.9 & 4 \\
460 to 479.9 & 12 \\
480 to 499.9 & 6 \\
500 to 519.9 & 2 \\
\hline Total & 43 \\
\hline
\end{tabular}

(ii) Level of wages, 1954

\begin{tabular}{l|c}
\hline \multicolumn{1}{c|}{$£$} & $\begin{array}{c}\text { Number of } \\
\text { Industries }\end{array}$ \\
\hline Under 680 & 3 \\
680 and under 700 & 5 \\
700 and under 720 & 5 \\
720 and under 740 & 5 \\
740 and under 760 & 3 \\
760 and under 780 & 4 \\
780 and under 800 & 5 \\
800 and under 820 & 9 \\
820 and under 840 & 3 \\
840 and over & 1 \\
\hline Total & 43 \\
\hline Mean & 755.14 \\
Standard deviation & 52.60 \\
Coefficient of variation & 6.97 \\
Ratio of upper to lower \\
quartile \\
Ratio of highest to lowest \\
wage \\
\hline
\end{tabular}

(iv) Percentage change in wages, 1947 to 1954

\begin{tabular}{l|c}
\hline \multicolumn{1}{c|}{$\%$} & $\begin{array}{c}\text { Number of } \\
\text { Industries }\end{array}$ \\
\hline 110 to 119.9 & 1 \\
120 to 129.9 & 1 \\
130 to 139.9 & 13 \\
140 to 149.9 & 15 \\
150 to 159.9 & 5 \\
160 to 169.9 & 7 \\
170 to 179.9 & 1 \\
\hline Total & 43 \\
\hline
\end{tabular}

ranged from 6.12 per cent in the Brewing industry to 29.81 per cent in the Motor Vehicles industry, the average proportion being 15.43 per cent. The lowest value of the change in the total unskilled male employment was observed in the Rope and Cordage industry $(-20.5$ per cent) and the highest in the Motor Vehicle industry $(+89.7$ per cent); the average change was $+19 \cdot 6$ per cent. 


\section{Results}

The distribution of average wages of unskilled male employees and the analysis of change is shown in Table I. It appears that the percentage differentials have become somewhat narrower while the absolute dispersion of wages increased. This tendency parallels the experience of the United States and other countries mentioned earlier. The value of Spearman's coefficient of rank correlation between wages in 1947 and in 1954 is 0.839 , which indicates some re-ranking, though not very substantial.

The test of the economic hypothesis has been carried out by obtaining least squares estimates of the regression coefficients and their standard errors. The statistical validity of the test depends on the assumptions about the disturbance term. The hypothesis of Dunlop (Model I) has been tested by constructing two regression equations; these differ only with respect to the measure of the degree of competition used. The estimates are as follows:

Model IA (Dunlop's)

$$
\begin{aligned}
& \Delta \hat{W}_{t}=264.804+1.750 P_{i}+0.115 O_{i}-1.073^{* *} C_{i}+ \\
& (0.899) \quad(0.186) \quad(0.363) \\
& +0.396 G_{i}+0.970 M_{i} ; R^{2}=0.397^{*} \\
& (0.452) \quad(0.775)
\end{aligned}
$$

Model IB (Dunlop's)

$$
\begin{aligned}
\Delta \hat{W}_{i} & =208.221+\underset{(0.879)}{2.210^{*}}+\underset{(0.180)}{0.085} O_{i}-0.869^{*} C_{i}+ \\
& +0.555 E_{i}+0.471 M_{i} \quad ; R^{2}=0.430^{* *}
\end{aligned}
$$

* = statistically significant at five per cent level;

* = statistically significant at one per cent level;

$\Delta W=$ change in average wage of unskilled male workers in pounds;

$P=$ ratio of output per unskilled male equivalent in 1954 (measured in 1947 prices) to that of 1947, multiplied by 100;

$O=$ ratio of 1954 output (measured in 1947 prices) to 1947 output, multiplied by 100 ;

$C=$ labour cost as a percentage of total direct costs;

$G=$ percentage gross profit margin;

$E=$ index of the concentration of employment in percentages;

$M=$ unskilled male migrant employment as a percentage of total unskilled male employment.

The following results tend to emerge:

(i) The degree of relationship, though highly significant, leaves a large proportion of variations in wage changes unexplained.

(ii) The only two relevant variables appear to be the rate of change in 
the productivity of labour and the labour cost percentage, the former having a positive and the latter a negative effect. ${ }^{33}$

(iii) The influx of migrants does not seem to have had a significant effect on the changes in the wage structure.

A test of Johansen's model rendered the following regression estimates:

Model II (Johansen's)

$$
\begin{aligned}
& \hat{W}_{1}=860.813-0.942 P_{\imath}+0.047 N_{\imath}-2.292^{* *} C_{\imath}+ \\
& \begin{array}{lll}
(1.521) \quad(0.303) \quad(0.605)
\end{array} \\
& +0.584 G_{i}+1.315 M_{i} ; R^{2}=0.303^{* *} \\
& (0.759) \quad(1.275)
\end{aligned}
$$

where, in addition to the previously used symbols,

$$
\begin{aligned}
\hat{W}= & \text { average wage of an unskilled male in } 1954 \text { in pounds; } \\
N= & \text { ratio of } 1954 \text { to } 1947 \text { employment of unskilled males, multiplied } \\
& \text { by } 100 .
\end{aligned}
$$

Here the degree of relationship is even lower than in the case of Dunlop's models, but it is still highly significant. An interesting feature of the results is the lack of significance of all explanatory variables except $C$, the labour cost percentage, which is negatively correlated with the level of wages.

So far our results have been somewhat disappointing, at least concerning the predictive power of the models. A further avenue worth exploiting is suggested by the observation of W. B. Reddaway ${ }^{3 t}$ who examined the relationship between changes in earnings and in employment in Great Britain and found that the correlation was greatly improved if the original 111 manufacturing industries were congested into 14 large industrial groups. A possible reason for this is that industries are heterogeneous with respect to influences on wage changes. In the calculation of the original correlation coefficient both small and large industries were equally influential; after the industrial groups were enlarged, the larger industries assumed a more predominant role. This implies a difference between small and large industries with respect to the forces underlying the changes in wages. It is conceivable that the mechanics of wage determination in large industries differs from that in small industries because of the possible differences in market and production conditions (e.g. differences in factor and product substitution, in economies of scale, etc.). This has been considered and, accordingly, our 43 industries have been divided into two groups, "large" industries and "small" industries. "Large" industries were defined as those with output in excess of $£ 10$ million in 1947; the remaining industries were classified as "small". The dividing line is somewhat arbitrary; it was chosen partly because it divides the industries into two approximately equal groups, and

\footnotetext{
s3 Strictly speaking, the value of the estimated regression coefficient attached to $P$ in Model IA is significant only at six per cent level.

84 "Wage Flexibility and the Distribution of Labour", Lloyds Bank Review, No. 54 (October 1959).
} 
partly because of a gap in the frequency distribution around the $£ 10$ million mark. The group of "large" industries consists of 22 industries; these are marked by an asterisk in the list of industries given in the Appendix. This left 21 industries to be classified as "small". The basic characteristics of the two groups are shown in Table II. The estimates of the regression equation of Dunlop's and Johansen's models are shown below.

\section{TABLE II}

Means and Standard Deviations of Variables used in the Models (Standard deviations are shown in the brackets)

\begin{tabular}{|c|c|c|c|c|}
\hline Variable & Unit & Large Industries & Small Industries & All Industries \\
\hline$\Delta^{\prime} W$ & $£$ & $\begin{array}{c}454 \\
(35 \cdot 0)\end{array}$ & $\begin{array}{c}439 \\
(30 \cdot 7)\end{array}$ & $\begin{array}{c}447 \\
(\mathbf{3 3} .8)\end{array}$ \\
\hline$W$ & $£$ & $\begin{array}{c}770 \\
(56.1)\end{array}$ & $\begin{array}{c}740 \\
(43.5)\end{array}$ & $\begin{array}{c}755 \\
(52 \cdot 6)\end{array}$ \\
\hline $\boldsymbol{P}$ & ratio & $\begin{array}{c}0.968 \\
(0.058)\end{array}$ & $\begin{array}{c}0.972 \\
(0.050)\end{array}$ & $\begin{array}{c}0.970 \\
(0.054)\end{array}$ \\
\hline 0 & " & $\begin{array}{c}1.106 \\
(0.205)\end{array}$ & $\begin{array}{c}1.219 \\
(0.289)\end{array}$ & $\begin{array}{c}1.161 \\
(0.256)\end{array}$ \\
\hline$N$ & $"$ & $\begin{array}{l}1.157 \\
(0.201)\end{array}$ & $\begin{array}{c}1.236 \\
(0.303)\end{array}$ & $\begin{array}{c}1.196 \\
(0.259)\end{array}$ \\
\hline$c$ & $\%$ & $\begin{array}{l}19.5 \\
(18.9\end{array}$ & $\begin{array}{c}28.1 \\
(12.1)\end{array}$ & $\begin{array}{r}23.7 \\
(13.8)\end{array}$ \\
\hline$G$ & $\%$ & $\begin{array}{c}24.0 \\
(11.8)\end{array}$ & $\begin{array}{l}31.1 \\
(7.7)\end{array}$ & $\begin{array}{c}27.5 \\
(10.6)\end{array}$ \\
\hline $\boldsymbol{E}$ & $\%$ & $\begin{array}{c}55.6 \\
(14.3)\end{array}$ & $\begin{array}{c}46.6 \\
(12.7)\end{array}$ & $\begin{array}{c}51.2 \\
(14.3)\end{array}$ \\
\hline $\boldsymbol{M}$ & $\%$ & $\begin{array}{l}12.7 \\
(5.8)\end{array}$ & $\begin{array}{l}15.4 \\
(6.0)\end{array}$ & $\begin{array}{c}14.0 \\
(6.0)\end{array}$ \\
\hline
\end{tabular}

LARGE INDUSTRIES

Model IA (Dunlop's)

$$
\begin{aligned}
& \Delta \hat{W}_{i}=410.821+0.297 P_{i}+0.214 O_{i}-1.821{ }^{* *} C_{i}+ \\
& \begin{array}{lll}
(1.066) \quad(0.356) \quad(0.433)
\end{array} \\
& +0.574 G_{i}+1.015 M_{i} ; R^{2}=0.625^{* *} \\
& (0.507) \quad(1.213)
\end{aligned}
$$

Model IB (Dunlop's)

$$
\begin{aligned}
& \Delta W_{t}=333.964+0.851 P_{t}+0.130 O_{t}-1.910^{* *} C_{t}+
\end{aligned}
$$

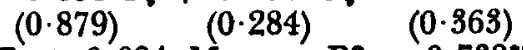

$$
\begin{aligned}
& +\underset{(0.363)}{1.075^{* *} E_{i}}+\underset{(0.962)}{0.084} M_{i} ; \quad R^{2}=0.738^{* *}
\end{aligned}
$$

Model II (Johansen's)

$$
\begin{aligned}
& \hat{W}_{\imath}=1,086.071-3.038 P_{i}+0.071 N_{i}-3.464^{* *} C_{q}+ \\
& (1.804) \quad(0.574) \quad(0.711) \\
& +0.922 G_{i}+1.221 M_{i} ; R^{2}=0.604^{* *} \\
& (0.845) \quad(1.906)
\end{aligned}
$$


SMALL INDUSTRIES

Model IA (Dunlop's)

$$
\begin{aligned}
& \Delta \hat{W}_{\imath}=32.690+3.668^{* *} P_{\imath}+0.130 O_{\imath}+0.401 C_{\imath}+ \\
& +0.001 G_{i}+1.477 M_{i} ; R^{2}=0.513^{* *} \\
& \text { (0.901) (0.985) }
\end{aligned}
$$

Model IB (Dunlop's)

$$
\begin{aligned}
\Delta W_{i}= & 38.721+3.621^{* *} P_{i}+0.142 O_{i}+\underset{(0.383}{0.504)} C_{i}- \\
& -0.077 E_{i}+1.556 M_{i} ; R^{2}=0.604^{* *} \\
& (0.548) \quad(1.115)
\end{aligned}
$$

\section{Model II (Johansen's)}

$$
\begin{aligned}
\hat{W}_{i}= & 508.569+1.875 P_{i}+0.132 N_{i}+\underset{(1.069)}{0.069 C_{i}-} \\
& \begin{array}{c}
(2.265) \quad 0.236 G_{i}+2.445 M_{i} ; R^{2}=0.205^{*} \\
(1.664) \quad(1.811)
\end{array}
\end{aligned}
$$

It is immediately apparent that the empirical fit is considerably improved when the industries are divided into two groups according to size. Further, the variables that tend to account for the observed inter-industry wage differentials in the two groups of industries are different. Considering first the hypothesis of Dunlop which attempts to explain the inter-industry differences in the change of wages we come to the following conclusions:

(i) In large industries the change in wages is to a high degree determined by the ratio of labour costs to total costs and by the degree of concentration of employment. The first of these variables has a negative, and the second a positive effect on the change in wages. Other variables postulated by Dunlop do not appear to have exercised a significant influence on the change in wages in large industries.

(ii) In small industries the only significant factor in explaining wage changes was found to be the productivity of labour which alone has accounted for a high degree of inter-industry variation in wage changes.

These conclusions bring out an interesting distinction in the forces affecting wage changes in small and in large industries. The dominance of labour productivity in small industries is consistent with the operation of the traditional market mechanism. An increase in labour productivity results in an upward shift in the labour demand curve and consequently in an increase in wages. On the other hand, in large industries the change in wages tends to vary with the importance of labour costs in the budget of the employers (the variation being negative, of course) and with the degree of monopoly on the product market as measured by the concentration of 
employment. Here the dominant factor seems to be the ability of the employer to pass on any wage increases demanded by labour-or his willingness to reduce profits-rather than the productivity of labour. Obviously, an employer is more able to pass on a wage increase in the form of a price rise if the rise in price is relatively small (i.e. if labour costs are small relative to other costs) or if he is in a near-monopolistic position.

Turning to Johansen's model which is designed to explain the interindustry differences in the level of wages at the end of the period we find that the relationship is reasonably high only in the case of large industries. Here the only relevant variable influencing the final level of wages turned out to be the ratio of labour costs to total costs. In the case of small industries none of the postulated explanatory variables appeared to be significant; their joint variation, however, made the degree of overall relationship just statistically significant at the five per cent level. On the whole, Johansen's model is less successful than Dunlop's. The main variables postulated by Johansen as the likely explanatory factors of the inter-industry wage structure-change in labour productivity and change in employment-did not appear to be relevant at all according to our estimated regression equations. This may be due, at least in part, to the lack of a trend in the productivity of labour which is one of Johansen's basic assumptions.

\section{Conclusion}

The results of our tests seem to lend somewhat more support to Dunlop's than to Johansen's hypothesis, but neither model has a high predictive power when all industries are considered jointly. However, if Dunlop's hypothesis is tested separately for small and for large industries, the relationship is greatly improved. But even then not all of the explanatory variables postulated by Dunlop appear to have influenced the change in wages and thus the hypothesis cannot be accepted in an unqualified way. In small industries the relevant variable was found to be the productivity of labour while in large industries the significant factors were the percentage labour cost and the concentration of employment. The remaining explanatory variables-the change in output and the relative employment of migrantshave had no apparent influence on the wage structure. The failure of the change in output to be positively associated with the change in wages is somewhat surprising particularly since wages, according to our definition, included overtime payments as well. In the case of large industries this may be attributed to the rather high degree of positive correlation between change in output and proportion of migrants employed $(r=0.581)$. Thus any relative scarcity of labour was probably mitigated by drawing upon the pool of new arrivals rather than by bidding for labour employed in other industries. For small industries, however, this does not seem to apply. The failure of the migration factor to exercise any influence on the relative 
change in wages is probably due to the concurrent changes in demand for products. Other things being equal, a relatively larger influx of migrants into any particular industry would tend to depress the average wage in this industry, or at least slow down its increase. However, if there is a concurrent increase in demand for the industry's product, this will act as an offsetting factor and wages will not necessarily decrease or increase more slowly than in other industries. In larger industries this explanation is consistent with the fact that relatively more migrants were to be found in the industries with relatively greater increases in output.

Perhaps the most important aspect of our investigation is the discovery of the distinction between small and large industries with respect to the factors operating on the wage structure in Australia. This has not been specifically considered in the studies of the subject in other countries and it may or may not be unique to the Australian economic environment. The important difference turned out to be the importance of labour productivity in small industries and of "bargaining" variables in large industries. The failure of labour productivity to be influential on wage changes in large industries is certainly highly surprising and seems to deserve a closer study of individual industries.

In general, our findings tend to vindicate the usefulness of economic theory as well as demonstrate its limitations. The economic hypothesis of Dunlop, when qualified and applied to different size groups, makes a definite contribution to the explanation of changes in the inter-industry wage structure. Institutional regulations, social and political factors, and balances of interest apparently mitigated, but did not fully eliminate the forces of the market mechanism. The voice of a theoretical economist, though muted, should still be heard. 
Appendix

Definition of Industries

\begin{tabular}{|c|c|c|}
\hline No. & Title of industry & Production bulletin classification \\
\hline 1 & Lime and Plaster & $\begin{array}{l}\text { Lime; Plaster of Paris; Asphalt; Fibrous Plaster and } \\
\text { Products }\end{array}$ \\
\hline 2 & Stone Processing & Marble; Slate; etc. \\
\hline $\mathbf{3}$ & Cement & Cement; Portland; Other Cement Goods \\
\hline 4 & Bricks and Pottery & $\begin{array}{l}\text { Bricks and Tiles; Earthenware; China; Porcelain and } \\
\text { Terra-cotta }\end{array}$ \\
\hline 5 & Glass & Glass; Glass Bottles \\
\hline $6 *$ & Drugs and Cosmetics & $\begin{array}{l}\text { Pharmaceutical and Toilet Preparations; Soap and } \\
\text { Candles }\end{array}$ \\
\hline 7 & Petroleum & Oils; Mineral \\
\hline 8* & Chemical & $\begin{array}{l}\text { Industrial and Heavy Chemicals and Acids; Explosives; } \\
\text { White Lead, Paints and Varnish; Vegetable Oils; } \\
\text { Chemical Fertilizers; Inks, Polishes, etc.; Matches; } \\
\text { Other Chemical }\end{array}$ \\
\hline $9 *$ & Metal Processing & $\begin{array}{l}\text { Smelting, Converting, etc. of Iron and Steel Foundries; } \\
\text { Non-Ferrous Metals-Rolling and Extrusion; Non- } \\
\text { Ferrous Metals-Founding, Casting, etc.; Galvanized } \\
\text { Ironworking and Tinsmithing; Pipes, Tubes, Fit- } \\
\text { tings, Ferrous; Lead Mills }\end{array}$ \\
\hline $10 *$ & $\begin{array}{l}\text { Refining of Non- } \\
\text { ferrous Metals }\end{array}$ & Extracting and Refining of Other Metals; Alloys \\
\hline $11 *$ & $\begin{array}{l}\text { Tram and Railway } \\
\text { Cars }\end{array}$ & $\begin{array}{l}\text { Construction and Repair of Tramcars and Railway } \\
\text { Rolling Stock }\end{array}$ \\
\hline $12 *$ & Automobile & $\begin{array}{l}\text { Motor Vehicles_Construction and Assembly; Motor } \\
\text { Bodies; Motor Accessories }\end{array}$ \\
\hline 18 & Aircra & Aircraft_Construction and Repair \\
\hline $14 *$ & Shipbuilding & Ship and Boat Building and Repairing \\
\hline 15 & Wire & Wire and Wire Working \\
\hline $16^{\circ}$ & Engineering & $\begin{array}{l}\text { Plant, Equipment and Machinery; Other Engineering; } \\
\text { Electrical Machinery, Cables and Apparatus; Cutlery } \\
\text { and Small Hand Tools; Agricultural Machines and } \\
\text { Implements; Gas Fittings and Meters; Sewing Mach- } \\
\text { ines; Arms, Ammunition; Wireless and Amplifying } \\
\text { Apparatus; Other Metal Works }\end{array}$ \\
\hline 17 & Jewel & Jewellery; Watches and Clocks \\
\hline 18 & Electroplating & Electroplating \\
\hline $19 *$ & Leather Processing & Tanning, Currying and Leather Dressing \\
\hline 20 & Leather Goods & $\begin{array}{l}\text { Machine Belting; Bags, Trunks and Other Leather } \\
\text { Goods }\end{array}$ \\
\hline $21 *$ & $\begin{array}{l}\text { Fur and Wool } \\
\text { Processing }\end{array}$ & $\begin{array}{l}\text { Furriers and Fur-dressing; Woolscouring and Fell- } \\
\text { mongery; Saddlery }\end{array}$ \\
\hline 22 & Rope and Cordage & Rope and Cordage \\
\hline $23 *$ & Textile & $\begin{array}{l}\text { Cotton Spinning and Weaving; Wool Spinning and } \\
\text { Weaving; Rayon, Nylon, Other Synthetic Fibres; Flax } \\
\text { Mills; Canvas Goods; Bags and Sacks; Other Textiles }\end{array}$ \\
\hline $24^{*}$ & Clothing & $\begin{array}{l}\text { Hosiery and Other Knitted Goods; Tailoring; Water- } \\
\text { proof Clothing; Dressmaking; Millinery; Shirts, Under- } \\
\text { clothing; Foundation Garments; Handkerchiefs, Ties, } \\
\text { Scarves; Hats and Caps; Gloves; Other Clothing }\end{array}$ \\
\hline $25^{\bullet}$ & Shoe Manufacturing & Boots and Shoes; Boot and Shoe Accessories \\
\hline 26 & Grain Proce & nilling; Cereals \\
\hline $27 *$ & Bakeries & Bakeries; Biscuits \\
\hline
\end{tabular}




\begin{tabular}{|c|c|c|}
\hline No. & Title of industry & Production bulletin classification \\
\hline $\begin{array}{l}28 * \\
29 \\
30 \\
311^{\circ} \\
32^{*}\end{array}$ & $\begin{array}{l}\text { Milk Products } \\
\text { Brewing } \\
\text { Wine } \\
\text { Tobacco } \\
\text { Food Processing }\end{array}$ & $\begin{array}{l}\text { Butter; Cheese; Condensed and Dry Milk } \\
\text { Breweries; Malting; Bottling } \\
\text { Distilleries and Wine-making; Cider and Perry } \\
\text { Tobacco; Cigars; Cigarettes } \\
\text { Bacon Curing; Margarine; Meat and Fish Preserving; } \\
\text { Sausage Skins; Oils, Animal; Boiling-down; Tallow- } \\
\text { refining }\end{array}$ \\
\hline $33^{\circ}$ & $\begin{array}{l}\text { Miscellaneous } \\
\text { Food Products }\end{array}$ & $\begin{array}{l}\text { Confectionery; Jam, Fruit and Vegetable Canning; } \\
\text { Pickles, Sauces, Vinegar; Condiments, Coffee, Spices; } \\
\text { Dehydrated Fruit and Vegetables; Arrowroot; Other } \\
\text { Food Products }\end{array}$ \\
\hline 34* & Wood Processing & $\begin{array}{l}\text { Sawmills; Plywood Mills; Bark Mills; Cooperage; Boxes } \\
\text { and Cases; Woodturning, Woodcarving; Basketware } \\
\text { and Wickerware; Wall and Ceiling Boards; Other } \\
\text { Wood Processing }\end{array}$ \\
\hline 35 & $\begin{array}{l}\text { Minor Home } \\
\text { Furnishing }\end{array}$ & $\begin{array}{l}\text { Bedding and Mattresses; Furnishing Drapery; Picture } \\
\text { Frames; Blinds }\end{array}$ \\
\hline $36 *$ & Printing & Printing \\
\hline 37 & Stereotyping & $\begin{array}{l}\text { Stereotyping, Electrotyping; Process and Photo-engrav- } \\
\text { ing }\end{array}$ \\
\hline $38 *$ & Stationery & $\begin{array}{l}\text { Manufactured Stationery; Cardboard Boxes; Paper Bags; } \\
\text { Paper-making; Pencils, Chalks; Other Paper and } \\
\text { Stationery }\end{array}$ \\
\hline 39 & Tyre Retreading & Tyre Retreading and Repairing \\
\hline 40 & Musical Instruments & Musical Instruments (all types) \\
\hline 41 & Plastic & Plastic Moulding and Products \\
\hline 42 & Optical Instruments & $\begin{array}{l}\text { Optical Instruments; Surgical and Other Scientific } \\
\text { Instruments }\end{array}$ \\
\hline 43 & Brooms and Brushes & Brooms and Brushes \\
\hline
\end{tabular}

